University at Albany, State University of New York

Scholars Archive

2010

\title{
Latin American and Spanish online videos: vendor offerings for US academic libraries
}

Jesús Alonso-Regalado

University at Albany, State University of New York, jalonso-regalado@albany.edu

Follow this and additional works at: https://scholarsarchive.library.albany.edu/ulib_fac_scholar

Part of the Collection Development and Management Commons

\section{Recommended Citation}

Alonso-Regalado, Jesús, "Latin American and Spanish online videos: vendor offerings for US academic libraries" (2010). University Libraries Faculty Scholarship. 3.

https://scholarsarchive.library.albany.edu/ulib_fac_scholar/3

This Article is brought to you for free and open access by the University Libraries at Scholars Archive. It has been accepted for inclusion in University Libraries Faculty Scholarship by an authorized administrator of Scholars Archive. For more information, please contact scholarsarchive@albany.edu. 


\title{
Latin American and Spanish Online Videos: Vendor Offerings for US Academic Libraries
}

\author{
License for this version:

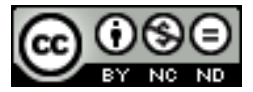 \\ http://creativecommons.org/licenses/by-nc-nd/3.0/us/ \\ Published in Emerald Journal “Collection Building” 29.1 (2010): 31-36. \\ Article URL: emeraldinsight.com/10.1108/01604951011015286
}

\begin{abstract}
Purpose: The purpose of this article is to explore the availability and features of Latin American and Spanish online videos available through video vendors and other providers to US academic libraries.

Design/methodology/approach: The paper examines US, Spanish, and Latin American video vendors that offer online videos about and/or produced in Latin America and Spain. The study focuses on: content, technical aspects, and terms of purchase. For video vendors providing digital delivery systems, searching capabilities and special features are also analyzed. The author also evaluates video providers interested in working with academic libraries. The availability of videos integrated in major multimedia databases is also explored.

Findings: The paper concludes that the Spanish and Latin American online video marketplace for academic libraries is still emerging, especially for those video vendors located abroad. The relatively small number of offerings are mostly documentaries. Streaming via internet protocol access is the most common way of delivery. Term licenses are standard and access is allowed both off-campus and on-campus.
\end{abstract}


Originality/value: Little research has been done on the availability of Latin American and Spanish online videos. This research would be especially useful for librarians responsible for collection development in these subject areas.

Keywords: Collections Management, Latin America, Spain, Vendors, Video

Paper type: Research paper

\section{Introduction}

The use of video to support research and teaching is increasing among professors, researchers, and students. In research, video resources are becoming more valued as primary and secondary source materials. In teaching, videos are used as a tool to illustrate and enhance course content, to encourage discussion in the classroom, and to promote new and diverse ideas and perspectives within the curriculum. This medium provides images that reflect the complexity and richness of our ever-expanding world in ways that text alone cannot.

New technology developments, such as the exponential increase of the bandwidth of internet connections, have expanded the possibilities of accessing videos online. Likewise, library users expect $24 / 7$ access not only to electronic textual and data resources but also to audiovisual materials. Video-on-Demand (VOD), defined as video available anytime from anywhere, is becoming prevalent on the internet.

The purpose of this article is to explore the current marketplace for online videos about Latin American and Spanish studies (including US Latino studies) and videos produced in Latin American and Spanish countries. The research focuses on video vendors available to US academic libraries. The research questions investigated are:

1. Which vendors offer Latin American and Spanish online video resources to US academic libraries? 
2. What characteristics are common among these vendors?

3. How are their videos accessed?

This research would be especially useful for Latin American and Spanish studies (LASS) librarians whose collection development responsibilities include multimedia resources.

\section{Literature review}

LASS librarians have traditionally built collections focusing on books and journals (Block, 1990) but increasingly have been acquiring non-print materials (Rodriguez, 1998) and internet resources (Molloy, 2005). In today's technological environment, subject librarians are responsible for selecting digital as well as print publications. Online videos, however, are not yet commonly collected even though their subject matter may meet the information needs of faculty and students.

A few studies have provided general overviews of online video in academic libraries. Handman and Daressa (2008a, b) presented a white paper to the National Media Market which discussed issues such as institutional uses of video, digital delivery, and licensing models, from both the librarian's and the distributor's perspectives. In terms of empirical studies, the Independent Film Distributors' Licensing Consortium (2007a) surveyed media librarians about digital delivery, licensing, usage, and pricing. Its conclusions and recommendations (Independent Film Distributors' Licensing Consortium, 2007b) indicated that although radical changes are not expected in the near future, directors, producers, and funders should be prepared to address issues involving the distribution of online video. Listservs such as Videolib (https://calmail.berkeley.edu/manage/list/listinfo/videolib@lists.berkeley.edu) are currently encouraging discussions of these issues. The National Media Market (Schwarz, 2008) and The 
American Library Association's Video Round Table (Threatt, 2006) web sites include information on US video vendors.

Little research has been done on the emerging field of Latin American and Spanish online videos. A few articles have analyzed the characteristics of videos freely available on the internet (Sánchez Noriega, 2005) or specific open access projects (López, 2009). Within the Hispanic context, various fora and institutions have discussed the impact of online video. For example, the first Congress of Iberoamerican Culture recently organized a seminar on the internet as a new distribution channel for Iberoamerican cinema (Vilardell and Sánchez, 2008), and the Centre de Desenvolupament Audiovisual (CDA) has published a useful and detailed report about VOD producers and distributors in Spain (Alléne et al., 2007). However, most of the information focusing on the study of online videos provided by media distributors has been limited to brief product reviews or opinion pieces in newspapers and popular magazines.

Increasingly, knowledge of the print, audiovisual, and electronic publishing trade is a requirement for Latin American studies collection development positions (Alonso-Regalado and Van Ullen, 2009, p. 155). As the online video market develops, librarians must be familiar with this new format. This article contributes to the literature by exploring US, Spanish, and Latin American vendors that offer online videos related to and/or produced in Latin America and Spain.

\section{Methodology}

The author investigated Latin American, Spanish, and US vendors that offer LASS online videos to US academic libraries. The vendors analyzed were chosen from lists developed by Schwarz (2008) and Threatt (2006). Additional vendors were found by reviewing articles and other relevant sources, and by drawing upon the author's knowledge of the subject. Companies 
providing fewer than 10 online videos were excluded. Vendor information was initially gathered from each vendor's web sites but direct contact via email or phone was also used if further information was needed. Content analysis techniques were used to examine the data. For each video vendor, the following characteristics were evaluated: content (coverage, type of film, and source), technical aspects (delivery options, IP access and formats supported), and terms of purchase (licensing and pricing model and access options). Search capabilities and special features were analyzed for vendors with their own digital delivery systems. Database aggregators integrating videos as part of their multimedia products were also investigated for Latin American and Spanish content. Finally, potential video providers and organizations interested in working with academic libraries were identified.

\section{Findings}

Information gathered about vendors providing Spanish and Latin American online videos to academic libraries is presented in Tables I-III. The findings are divided into two sections: 1) US video vendors and 2) Spanish and Latin American video vendors.

\subsection{US video vendors}

\subsubsection{Educational and documentary video distributors}

Independent video vendors have a long tradition of distributing highly selective titles in various physical formats (e.g. VHS or DVD) to academic libraries. Table I includes information about US independent vendors that offer online documentaries related to Latin America and Spain in their catalogs. The number of titles ranges from over 60 to nearly 200. Independent producers and filmmakers are the main source of videos. 
The only delivery option allowed by these vendors is streaming via IP recognition from the local library server. The vendor sends a physical copy of the video, which the library converts into its preferred format. All of these independent companies offer licenses for each title separately. The length of license usually runs from one class or semester to one, two, three or five years but vendors tend to be flexible and willing to meet the library's needs. The most common pricing model is based on institution type according to the Carnegie classification. Inperpetuity licenses are uncommon. A few vendors such as Documentary Educational Resources and Bullfrog Films offer this option for some titles but only in rare instances. All of these vendors permit both on-campus and off-campus access to licensed online videos through library catalogs, other library platforms such as e-reserves, or online virtual learning systems such as Blackboard. Bullfrog Films is the only independent vendor specifically offering MARC records.

\begin{tabular}{|c|c|c|c|c|c|c|c|c|}
\hline \multirow[t]{2}{*}{ Video Vendor } & \multicolumn{3}{|c|}{ Content } & \multicolumn{3}{|c|}{ Technical aspects } & \multicolumn{2}{|c|}{ Terms of purchase } \\
\hline & No. & $\begin{array}{l}\text { Film } \\
\text { type }\end{array}$ & Source & Delivery options & $\begin{array}{c}\text { IP } \\
\text { access? }\end{array}$ & $\begin{array}{l}\text { Formats } \\
\text { supported }\end{array}$ & $\begin{array}{l}\text { Licencing } \& \\
\text { pricing model }\end{array}$ & $\begin{array}{l}\text { Campus } \\
\text { and/or } \\
\text { remote } \\
\text { Access? }\end{array}$ \\
\hline $\begin{array}{l}\text { Bullfrog Films } \\
\text { http://www.bullfrogfilms.com }\end{array}$ & +70 & $\mathrm{D}$ & $\begin{array}{l}\text { Filmakers } \\
\text { and } \\
\text { producers }\end{array}$ & $\begin{array}{l}\text { Streaming from } \\
\text { local library } \\
\text { server }\end{array}$ & Yes & $\begin{array}{l}\text { Any that } \\
\text { the library } \\
\text { can } \\
\text { support }\end{array}$ & $\begin{array}{l}\text { Term license } \\
\text { based on } \\
\text { institution } \\
\text { type (Carnegie } \\
\text { Classification). }\end{array}$ & Both \\
\hline $\begin{array}{l}\text { Cinema Guild } \\
\text { http://www.cinemaguild.com }\end{array}$ & +170 & $\mathrm{D}$ & $\begin{array}{l}\text { Producers } \\
\text { and sales } \\
\text { agents }\end{array}$ & $\begin{array}{l}\text { Streaming from } \\
\text { local library } \\
\text { server }\end{array}$ & Yes & $\begin{array}{l}\text { Any that } \\
\text { the library } \\
\text { can } \\
\text { support }\end{array}$ & Term license. & Both \\
\hline $\begin{array}{l}\text { Documentary Educational } \\
\text { Resources } \\
\text { http://www.der.org }\end{array}$ & +150 & $\mathrm{D}$ & $\begin{array}{l}\text { Producers } \\
\text { or } \\
\text { produced } \\
\text { by this } \\
\text { vendor }\end{array}$ & $\begin{array}{l}\text { Streaming from } \\
\text { local library } \\
\text { server }\end{array}$ & Yes & $\begin{array}{l}\text { Any that } \\
\text { the library } \\
\text { can } \\
\text { support }\end{array}$ & $\begin{array}{l}\text { Term license } \\
\text { based on size } \\
\text { of the targeted } \\
\text { academic } \\
\text { group. In- } \\
\text { perpetuity } \\
\text { license for } \\
\text { some titles. }\end{array}$ & Both \\
\hline
\end{tabular}




\begin{tabular}{|c|c|c|c|c|c|c|c|c|}
\hline $\begin{array}{l}\text { Filmakers Library } \\
\text { http://www.filmakers.com }\end{array}$ & +90 & $\mathrm{D}$ & $\begin{array}{l}\text { Producers } \\
\text { /broadcast } \\
\text { agents } \\
\text { abroad }\end{array}$ & $\begin{array}{l}\text { Streaming from } \\
\text { local library } \\
\text { server }\end{array}$ & Yes & $\begin{array}{l}\text { Any that } \\
\text { the library } \\
\text { can } \\
\text { support }\end{array}$ & Term license. & Both \\
\hline $\begin{array}{l}\text { Icarus Films } \\
\text { http://icarusfilms.com }\end{array}$ & +130 & $\mathrm{D}$ & $\begin{array}{l}\text { Mostly } \\
\text { producers }\end{array}$ & $\begin{array}{l}\text { Streaming from } \\
\text { local library } \\
\text { server }\end{array}$ & Yes & $\begin{array}{l}\text { Any that } \\
\text { the library } \\
\text { can } \\
\text { support }\end{array}$ & $\begin{array}{l}\text { Term license } \\
\text { based on } \\
\text { institution } \\
\text { type (Carnegie } \\
\text { Classification). }\end{array}$ & Both \\
\hline $\begin{array}{l}\text { Third World Newsreel } \\
\text { http://www.twn.org }\end{array}$ & +70 & $\mathrm{D}$ & Producers & $\begin{array}{l}\text { Streaming from } \\
\text { local library } \\
\text { server }\end{array}$ & Yes & $\begin{array}{l}\text { Any that } \\
\text { the library } \\
\text { can } \\
\text { support }\end{array}$ & $\begin{array}{l}\text { Term license } \\
\text { based on } \\
\text { budget size. } \\
\text { In-perpetuity } \\
\text { license for } \\
\text { some titles. }\end{array}$ & Both \\
\hline $\begin{array}{l}\text { Women Make Movies } \\
\text { http://www.wmm.com/ }\end{array}$ & +60 & $\mathrm{D}$ & $\begin{array}{l}\text { Filmakers } \\
\text { and } \\
\text { producers }\end{array}$ & $\begin{array}{l}\text { Streaming from } \\
\text { local library } \\
\text { server }\end{array}$ & Yes & $\begin{array}{l}\text { Any that } \\
\text { the library } \\
\text { can } \\
\text { support }\end{array}$ & $\begin{array}{l}\text { Term license } \\
\text { based on } \\
\text { institution } \\
\text { type (Carnegie } \\
\text { Classification). }\end{array}$ & Both \\
\hline
\end{tabular}

Two major video vendors, Film Media Group and Filmotech, have their own digital systems. Detailed information about these distributors is provided in Tables II and III. In contrast to the vendors in Table I, Film Media Group's videos are streamed via Films on Demand, its own digital delivery system which provides powerful search capabilities and added features including usage statistics. Users can also share video playlists and access specific segments within a video. Film Media Group adopts a licensing model that allows subscribing to individual titles, its entire catalog, or individual collections packaged by major disciplines: humanities and social sciences, business and economics, science, and health. Filmotech, a Spanish cinema portal, is more fully discussed in section 4.2. 
Table II. Vendors with their own digital video delivery systems offering Latin American and Spanish online videos for US academic libraries

\begin{tabular}{|c|c|c|c|c|c|c|c|c|}
\hline \multirow[t]{2}{*}{ Video Vendor } & \multicolumn{3}{|c|}{ Content } & \multicolumn{3}{|c|}{ Technical aspects } & \multicolumn{2}{|c|}{ Terms of purchase } \\
\hline & No. & $\begin{array}{l}\text { Film } \\
\text { type }\end{array}$ & Source & Delivery options & $\begin{array}{c}\text { IP } \\
\text { access? }\end{array}$ & $\begin{array}{l}\text { Formats } \\
\text { supported }\end{array}$ & $\begin{array}{l}\text { Licencing \& } \\
\text { pricing model }\end{array}$ & $\begin{array}{l}\text { Campus } \\
\text { and/or } \\
\text { Remote } \\
\text { Access? }\end{array}$ \\
\hline $\begin{array}{l}\text { Film Media Group } \\
\text { www.films.com/digital }\end{array}$ & +350 & $\mathrm{D}$ & $\begin{array}{l}\text { Mainly } \\
\text { producers } \\
\text { and } \\
\text { broadcast } \\
\text { companies }\end{array}$ & $\begin{array}{l}\text { Streaming is available } \\
\text { via its delivery system. } \\
\text { Downloading of video } \\
\text { titles to the library local } \\
\text { server is also available } \\
\text { but this option requires } \\
\text { to purchase a digital } \\
\text { license and purchase of } \\
\text { DVD. These titles } \\
\text { would be accessible to } \\
\text { the academic } \\
\text { community via } \\
\text { streaming. }\end{array}$ & Yes & $\begin{array}{l}\text { Flash, } \\
\text { Windows } \\
\text { Media and } \\
\text { Quicktime. } \\
\text { Other file } \\
\text { options are } \\
\text { also available } \\
\text { for } \\
\text { downloading. }\end{array}$ & $\begin{array}{l}\text { For collections: } \\
\text { Subscription } \\
\text { with fees } \\
\text { based first on } \\
\text { University } \\
\text { type (according } \\
\text { to the Carnegie } \\
\text { Classification) } \\
\text { and then FTE. } \\
\text { For individual } \\
\text { titles: Price } \\
\text { based on } \\
\text { content. In- } \\
\text { perpetuity } \\
\text { rights also } \\
\text { available. }\end{array}$ & Both \\
\hline $\begin{array}{l}\text { Filmotech } \\
\text { http://www.filmotech.com }\end{array}$ & +600 & $\begin{array}{l}\text { FF, } \\
D, \\
\text { and } \\
\text { short } \\
\text { films }\end{array}$ & Producers & $\begin{array}{l}\text { Streaming is available } \\
\text { via its delivery system. }\end{array}$ & Yes & Flash & $\begin{array}{l}\text { Negotiable } \\
\text { with academic } \\
\text { libraries. There } \\
\text { is not one pre- } \\
\text { established for } \\
\text { educational } \\
\text { institutions } \\
\text { yet. }\end{array}$ & Both \\
\hline $\mathrm{D}=\mathrm{Do}$ & e Fil & & & & & & & \\
\hline
\end{tabular}

Table III. Searching Capabilities and Special Features in video vendors included in Table II

\begin{tabular}{|c|c|c|c|}
\hline Video vendor & \multicolumn{2}{|l|}{ Search capabilities } & Special features \\
\hline $\begin{array}{l}\text { Film Media Group } \\
\text { www.films.com/digital }\end{array}$ & $\begin{array}{l}\text { Browsable subject categories: "Latin } \\
\text { American Studies" (under "Area } \\
\text { studies"), "Spanish" (under "World } \\
\text { Literature", including the following } \\
\text { sub-categories: "Spanish Culture \& } \\
\text { History", "Spanish Language" and } \\
\text { "Spanish Literature \& Drama"), and } \\
\text { "Latino Studies" (under "Sociology"). }\end{array}$ & $\begin{array}{l}\text { Search by subject, } \\
\text { producers, copyright date, } \\
\text { closed-captioned } \\
\text { program, and specific } \\
\text { video segments. }\end{array}$ & $\begin{array}{l}\text { Links to the videos can be integrated } \\
\text { in any library content management } \\
\text { system. Usage statistics feature and } \\
\text { MARC records are available. Options } \\
\text { for saving and sharing playlists, } \\
\text { segments and favorites are offered. } \\
\text { Provides citations for each video in } \\
\text { MLA and Chicago styles. }\end{array}$ \\
\hline $\begin{array}{l}\text { Filmotech } \\
\text { http://www.filmotech.com }\end{array}$ & $\begin{array}{l}\text { Browse by type of film, genre, most } \\
\text { viewed and new additions. }\end{array}$ & $\begin{array}{l}\text { Search by type of film, } \\
\text { genre, language version, } \\
\text { presence of subtitles, } \\
\text { country availability, } \\
\text { directors, cast, production } \\
\text { country, and year. }\end{array}$ & $\begin{array}{l}\text { Video segments available upon } \\
\text { request. }\end{array}$ \\
\hline
\end{tabular}




\subsubsection{Database and online collections vendors}

Major database vendors are increasingly incorporating digital streaming media into their full-text databases. These audiovisual resources enhance the learning and teaching experience. Unfortunately, videos can be difficult to locate among the massive amount of information stored in these databases.

The following list presents database products with some LASS video content:

- Proquest' Critical Mention iTV is a searchable database containing worldwide television news clips. It is useful for finding videos on current events. However, it only includes clips from the last month. Video coverage of Latin America is abundant, but it is mainly limited to US-based television channels.

- Proquest' Dissertation and Theses integrates information about videos used as supplemental files to dissertations, along with access to the videos themselves. For example, the dissertation, "To the Beat of a Different Drum: Basque Dance and Identity in the Homeland and the Diaspora," is accompanied by video files on Basque dances.

- Gale's Global Issues in Context allows the user to find news-related video clips dealing with current events and issues organized by country (including most Latin American nations) or by topic (such as post-Castro Cuba or US-Mexico border issues). Multimedia content is primarily provided by news sources such as Associated Press and the Public Broadcasting System (PBS).

- ABC-CLIO offers databases with minimal video content related to Latin America. United States at War includes a few historic films which are part of the Library of Congress' Spanish-American War in Motion Pictures Collection (http://memory.loc.gov/ammem/sawhtml/). 
World Geography; World History: Ancient and Medieval; and World History: the Modern Era also include some video clips on Latin American countries.

- EBSCO's Points of View Reference Center includes some historical videos provided by the Video Encyclopedia of the 20th Century for most Latin American countries.

- Alexander Street Press' America History on Video features a few Latin American and Spanish-related documentaries and some newsreel clips on historical Latin American issues.

\subsection{Spanish and Latin American video vendors}

The Spanish VOD market targets the individual consumer in Spain. Telecom providers such as Telefónica, Orange, and Jazztel offer their online video catalog via internet portals, but access is limited to Spain due to copyright restrictions. Specialized portals such as Yodecido (http://www.yodecido.com/) distribute online films for rent or purchase with restrictions similar to those of the telecom providers.

A few Spanish initiatives have shown some preliminary interest in establishing services for libraries. Filmin (http://www.filmin.es) is a project initiated in 2008 by several prominent independent Spanish film companies. It offers a selective video catalog of independent films, which in a few cases are released on the internet and theaters simultaneously. Part of its online video content is freely available. The Sociedad General de Autores y Editores (SGAE), a rights management society, has created its digital distribution platform which offers audiovisual materials to telecom providers and portals, such as Yodecido, or via its own portal Tramart (http://tramart.es/).

Filmotech (http://www.filmotech.com), a Spanish cinema portal providing access to a large audiovisual catalog (see Tables II and III), has already started to work with US academic 
libraries. This project has been developed by Entidad de Gestión de Derechos de los Productores Audiovisuales (EGEDA), a producers' rights management organization representing more than 70 per cent of the Spanish film production companies. Filmotech includes a large number of titles from Spain and a growing list of Latin American titles. In the last few years, it has been providing institutional licenses for streaming video to academic libraries that have requested them. A recent panel discussion held at the SALALM (Seminar on the Acquisition of Latin American Library Materials) conference in Berlin presented Filmotech's video catalog to a wide audience of LASS librarians, showing Filmotech's growing interest in the academic library market (Sánchez, 2009).

Docfera (http://www.docfera.com/) is an ambitious project aimed at becoming the prime gateway and digital archives of Latin American documentaries. Currently, over 100 titles (all selectively curated by experts) are available for purchase to individuals as downloadable copies. Docfera is establishing an open discussion with Latin American studies faculty and librarians to explore ways of licensing online access to academic institutions.

\section{Discussion}

The number of Latin American and Spanish online videos provided by vendors is still scarce. This figure will grow over time, but just as some VHS tapes have never been reformatted as DVDs, some titles may never be converted to online formats. An added issue is the availability of online videos that include subtitles. Providing subtitles would allow for increased use beyond the current LASS-related curricula. The internet multiplies the potential of finding films that were never released in the US in theaters or on video. Likewise, it increases the exposure of hard-to-find films in physical formats. The vast majority of vendors' catalogs are 
heavily focused on documentaries due to a larger demand in academic libraries for non-fiction audiovisual materials. There are a few exceptions, such as Filmotech whose catalog offers both feature films and documentaries.

Streaming has become the standard way of delivering video on the internet. IP access is also widely accepted by vendors who are experienced in working with libraries. However, vendors who have not provided services for libraries before need to be educated in the problems of administrating password access. In most cases, videos are presented in a relatively small screen size. This viewing experience, however, is well received by users because they are accustomed to this size and image quality. Full screen mode with high definition quality or standard DVD definition is infrequent in the online video market for academic libraries, with only a few exceptions like the Spanish portal Filmotech and the US vendor Film Media Group. For this latter company, full-view quality is currently being introduced. Independent video vendors for academic libraries have focused more on the quality of the product rather than on providing services such as searching capabilities and added features. Therefore, digital delivery platforms with these services are the exception and are offered only by major video companies. Alexander Street Press is currently offering the most sophisticated video delivery system for library and educational institutions. Videos are semantically indexed, may be viewed along with their transcripts, custom clips can be manually created, and transcripts are searchable.

Term licenses are the most common access models available to academic libraries, only a few companies provide in-perpetuity rights. This may reflect the fact that academic libraries are acquiring online videos as a way to extend access, rather than to build a collection for the future. Libraries that want to build permanent online video collections may be able to negotiate customized licensing options. Pricing is normally based on a title-by-title basis. Certain vendors 
who may lack experience working with libraries have contemplated only providing a pay-perview model. This pricing type can be difficult to implement for libraries that need to predict costs.

Licensing and pricing models applied to Latin American and Spanish videos are not based on real demand as these titles are going to be viewed only by a small number of people within the academic institution. Instead of using a model based on the number of students, type of university, or overall library budget, criteria defined according to number of faculty and students in Latin American and Hispanic Studies programs would better reflect actual use.

Open access and legal license availability to online videos coexist on the internet. Some companies offer licensed videos exclusively. Others use a mixture of both open and licensed access. Video portals such as Filmotech include freely-available short films alongside its licensed online videos. Major vendors like Films Media Group incorporate videos from providers like PBS that are available in their publicly accessible web sites. Two reasons might justify acquiring videos that are also available for free. First, the time period during which the videos would be freely available is often unknown; Video vendors, however, guarantee secure access for the licensed term. Second, subscribed video services may include value-added features which will enhance the teaching and learning experience. Companies such as Gale and $\mathrm{ABC}$ CLIO offer multimedia databases that place open access videos in context and incorporate them along with text and other resources as a way to better illustrate ideas and generate new meanings. Advanced searching capabilities in the vendors' digital delivery systems can facilitate finding videos on specific topics. 
Films are generally released first in movie theaters and then on DVD, pay-per-view, and video-on-demand before being broadcast on TV. The time lag between each release ranges from months to years, and may vary depending on where the films were produced. Latin American and Spanish government agencies that support film production often establish release periods for each stage. Simultaneous releases have been explored in recent years. Online video portals such as Filmin and Filmotech are currently offering a few titles at the same time that they are being released in theaters. Faculty and students demand online access to video titles as soon as they are available on DVD. This may be a factor that helps promote the use of the online format in academic libraries.

\section{Conclusion}

The availability of LASS online videos provided by US vendors to academic libraries has increased in recent years. On the other hand, the online video market in Spain and Latin American countries is just emerging with a few providers currently exploring ambitious initiatives that will greatly expand libraries' access to online videos produced in those countries. Major US companies such as Netflix and Blockbuster, and independent ventures like Jaman (http://www.jaman.com) and The Auteurs (http://www.theauteurs.com) are offering online videos directly to consumers. None of these companies have plans to market these services to libraries, but subject specialists and media librarians should carefully monitor these companies and explore future opportunities. Communication between video vendors and librarians will be vital in shaping the future of online videos in academic libraries. A mutual understanding of how libraries and video vendors operate must be achieved. 
The present study focused on Latin American and Spanish online videos. Many other disciplines would benefit from a similar examination. Furthermore, the presence of freely available videos on the Internet has exponentially increased in just a few years and needs to be further analyzed. Anecdotal evidence suggests that academic libraries are not currently building comprehensive research online video collections, that their acquisition criteria are curriculum needs and potential use, and that their focus is on expanding access rather than preserving online videos for the future. More research is needed to understand the status of online video collections in US academic libraries and the viability of building permanent online video collections.

\section{References}

Alléne, H. with collaboration from, Monzón, M., Tuca, J. and Berger, L. (2007), "Video on demand: new frontiers for producers and distributors in Spain", Centro de Desenvolupament Audiovisual (CDA), Barcelona, available at:

www20.gencat.cat/docs/CulturaDepartament/ICIC/Documents/Arxiu ICIC/cinema on demand.pdf (accessed October 11, 2009).

Alonso-Regalado, J. and Van Ullen, M. (2009), "Librarian for Latin American and Caribbean studies in U.S. academic and research libraries: A content analysis of position announcements 1970-2007", Library Resources \& Technical Services, Vol. 53, No. 3, pp. 139-158.

Block, D. (Section Ed.) (1990), "Part 3. Iberia, Latin America and the Caribbean", in Johns, C. (Ed.), Selection of Library Materials for Area Studies, American Library Association, Chicago, IL, pp.125-384. 
Handman, G. and Daressa, L. (2008a), "Streamed video licensing: issues and challenges for sellers and buyers", available at: www.lib.berkeley.edu/MRC/vod08b.pdf (accessed October 11, 2009).

Handman, G. and Daressa, L. (2008b), "Streamed video licensing: issues and challenges for sellers and buyers. Video-on-Demand and Libraries: new vistas and new solutions", available at: www.lib.berkeley.edu/MRC/whitepapercomments.pdf (accessed October 11, 2009).

Independent Film Distributors' Licensing Consortium (2007a), "Digital delivery of video survey report", available at: http://www.docuseek.com/misc/IFDLC.survey.pdf (accessed October 11, 2009).

Independent Film Distributors' Licensing Consortium (2007b), "Digital delivery of video survey. Conclusions \& recommendations for directors, producers, and funders", available at: http://www.docuseek.com/misc/conclusions.pdf (accessed October 11, 2009). López, A. (2009), "Cine español en internet para la docencia, investigación y producción: canal web-mediateca en línea RTVDoc", Enl@ce: Revista Venezolana de Información, Tecnología y Conocimiento, Vol. 6, No.1, pp.99-111.

Molloy, M. (2005), "The internet in Latin America: development and reference sources", Journal of Library Administration, Vol. 43 Nos 3/4, pp. 129-147.

Rodriguez, K. (1998), "Collection patterns of selected disciplines of Latin American print and non-print materials", Collection Building, Vol. 17 No.3, pp. 129-39. 
Sánchez, R. (2009), "Filmotech.com: un portal legal de obras audiovisuales creado por iniciativa de los productores españoles", paper presented at the Seminar on the Acquisition of Latin American Library Materials (SALALM) $54^{\text {th }}$ Annual Conference, June 3-8, Berlin.

Sánchez Noriega, J. L. (2005), "Películas a golpe de ratón. Un exploración sobre el cine comprimido en la Red", Telos, No. 64, pp. 33-40.

Schwarz, U. (2008), "Digital rights available from National Media Market exhibitors", available at: www.nmm.net/forms/DigitalRightsMaster.pdf (accessed October 11, 2009).

Threatt, M. (2006), "Streaming video vendor grid", available at: http://www.ala.org/ala/mgrps/rts/vrt/vrtconferenceinfo/streamingvendor.cfm (accessed October 11, 2009).

Vilardell, E. and Sánchez, V. (coord.) (2008), "Comercialización del cine iberoamericano. modelo tradicional de comercialización vs. nuevos cauces de comercialización - la internet", Specialized Seminar part of the First Ibero-American Culture Congress, October 2, 2008. Mexico D.F. (CD-ROM). 